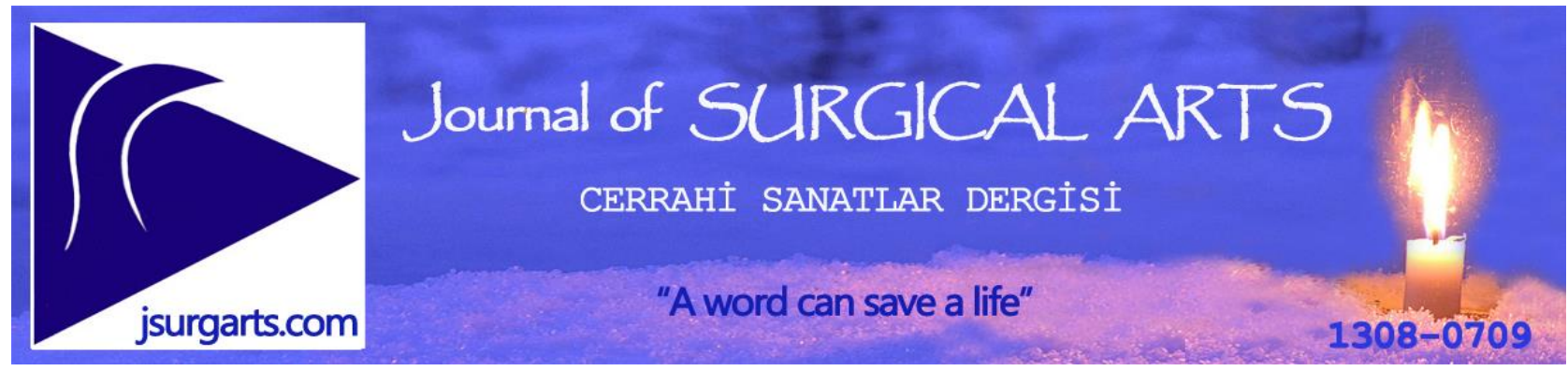

Clinical Practice Study

\title{
A clinical study of liver abscess in patients attending the surgical department. A single center experience.
}

\section{Cerrahi kliniğine gelen hastalarda karaciğer apsesinin klinik analizi. Tek merkez deneyimi.}

\author{
Vikram Yogish, Sunu Ancy Joseph, Velineni Bharath
}

SRM Medical College Hospital and Research Center, Department of General Surgery, Kattankulathur, Tamil Nadu, India.

Address: Dr. Vikram Yogish (https://orcid.org/0000-0003-4826-6644), yogishvikram@gmail.com

How to cite: Yogish V, Joseph SA, Bharath V. A clinical study of liver abscess in patients attending the surgical department. A single center experience. J Surg Arts: 2021;14(1):7-10. DOI: https://doi.org/10.14717/jsurgarts-210102

Received: 10/3/2020 Accepted: 11/11/2020

\section{ABSTRACT}

Liver abscess is a condition that is seen by surgeons all over the world. The patients present to the surgical department with features of right hypocondrial pain, fever and jaundice. Investigations such as ultrasound of the abdomen and CT scan of the abdomen are extremely useful in diagnosing a case of liver abscess. The two main causes of liver abscess are amoebic and pyogenic liver abscess. Occasionally a liver abscess may also occur due to fungal infection. Treatment modalities include the use of drugs such as metronidazole for amoebic liver abscess, as well as needle aspiration and pigtail catheter drainage when required. This was a prospective study was carried out from August 2015 to July 2018, for a period of three years. The study was conducted at SRM Medical College Hospital and Research Center, Kattankulathur, Tamil Nadu, India. Investigations such as complete blood count (CBC), chest $\mathrm{x}$-ray, $\mathrm{x}$-ray abdomen, ultrasound of the abdomen and CECT of the abdomen were done. A total of 57 patients were studied and the results obtained were analysed.

Keywords: Amoebic liver abscess, pyogenic liver abscess, metronidazole, needle aspiration.

\section{ÖZET}

Karaciğer apsesi, tüm dünyadaki cerrahlar tarafindan karşılaşılan bir durumdur. Hastalar sağ hipokondriyal ağrı, ateş ve sarılık özellikleri ile cerrahi bölümüne başvururlar. Karın ultrasonu ve karın BT taraması gibi araştırmalar karaciğer apsesi teşhisinde son derece yararlıdır. Karaciğer apsesinin iki ana nedeni amipli ve piyojenik karaciğer apsesidir. Bazen mantar enfeksiyonu nedeniyle de karaciğer apsesi oluşabilir. Tedavi yöntemleri arasında amipli karaciğer apsesi için metronidazol gibi ilaçların yanı sıra iğne aspirasyonu ve gerektiğinde pigtail kateter drenajı yer alır. Prospektif çalışmamızda Ağustos 2015'ten Temmuz 2018'e kadar üç yıllık bir süre boyunca kliniğimize gelen hastalar değerlendirmeye alındı. Çalışma SRM Medical College Hastanesi ve Araştırma Merkezi, Kattankulathur, Tamil Nadu, Hindistan'da gerçekleştirildi. Tam kan sayımı (CBC), göğüs röntgeni, karın röntgeni, karın ultrasonu ve karın CECT gibi incelemeler yapıldı. Toplam 57 hasta incelendi ve elde edilen sonuçları analiz edildi.

Anahtar kelimler: Amibik karaciğer apsesi, piyojenik karaciğer apsesi, metronidazol, aspirasyon. 


\section{INTRODUCTION}

Liver abscess is a condition that is seen by surgeons all over the world. The patients present to the surgical department with complaints of abdominal pain which is more over the right hypochondrium. The patient may also have fever and jaundice as well. A detailed history must be collected and a thorough clinical examination must be done. Investigations such as complete blood count (CBC), chest x-ray, x-ray abdomen and ultrasound of the abdomen must be done.

A contrast enhanced CT (CECT) of the abdomen will also be very useful. Liver abscess may be of certain types such as amoebic liver abscess and pyogenic liver abscess. Occasionally a liver abscess may also occur due to fungal infection. The treatment of a liver abscess depends on the aetiology as to whether it is an amoebic liver abscess or pyogenic liver abscess. Drugs such as metronidazole are very useful in cases of amoebic liver abscess. However, sometimes, aspiration of the abscess cavity may be required. The aspiration can be done using image guided techniques and if required a pigtail catheter can be placed inside the abscess cavity for continuous drainage. The pus that is drained should also be sent for culture and sensitivity. Surgical open drainage of the abscess is only occasionally indicated such as, if the abscess ruptures into the peritoneal cavity and if there are features of peritonitis. At times like these an exploratory laparotomy and open drainage will be needed. Our study deals with amoebic and pyogenic liver abscess in patients who presented to the surgical department at our hospital.

\section{MATERIAL and METHOD}

This was a prospective study carried out from August 2015 to July 2018, for a period of three years. The study was conducted at SRM Medical College Hospital and Research Center , Kattankulathur, Tamil Nadu , India. A detailed history was collected and a thorough clinical examination was done. Investigations such as complete blood count (CBC), chest x-ray, $\mathrm{x}$-ray abdomen, ultrasound of the abdomen and CECT of the abdomen were done. A total of 57 patients were studied and the results obtained were tabulated. The statistics were analysed using SPSS package 16.0. Ethical clearance was obtained from the institutional ethics committee.

\begin{tabular}{|l|l|l|}
\hline $\begin{array}{l}\text { Table 1: Age group of patients who had liver } \\
\text { abscess, n=57. }\end{array}$ \\
\hline $\begin{array}{l}\text { Age } \\
\text { (Years) }\end{array}$ & $\begin{array}{l}\text { Patients } \\
\text { (n) }\end{array}$ & $\begin{array}{l}\text { Percentage } \\
\text { \% }\end{array}$ \\
\hline $30-40$ & 8 & 14.0 \\
\hline $41-50$ & 18 & 31.57 \\
\hline $51-60$ & 21 & 36.84 \\
\hline $61-70$ & 7 & 12.28 \\
\hline $71-80$ & 3 & 5.26 \\
\hline
\end{tabular}

\section{RESULTS}

From the results, it is seen that in our study, liver abscess was most common between the age group of 51 to 60 years $(36.84 \%)$. 40 patients $(70.17 \%)$ had history of chronic alcohol intake (Table $1-7)$. Right hypochondrial pain $(84.21 \%)$ was the most common clinical feature with which the patients presented to the surgical department and many of these patients also had fever (78.94\%).

Table 2: Alcohol intake in patients with liver abscess, $\mathrm{n}=57$.

\begin{tabular}{|l|c|c|}
\hline \multicolumn{1}{|c|}{ Group } & $\begin{array}{c}\text { Patients } \\
\text { (n) }\end{array}$ & $\begin{array}{c}\text { Percentage } \\
\text { \% }\end{array}$ \\
\hline $\begin{array}{l}\text { Alcohol intake pre- } \\
\text { sent }\end{array}$ & 40 & 70.17 \\
\hline No alcohol intake & 17 & 29.82 \\
\hline
\end{tabular}

Table 3: Clinical features of the patients with liver abscess.

\begin{tabular}{|l|c|c|}
\hline \multicolumn{1}{|c|}{ Clinical feature } & $\begin{array}{c}\text { Patients } \\
\text { (n) }\end{array}$ & $\begin{array}{c}\text { Percentage } \\
\text { \% }\end{array}$ \\
\hline $\begin{array}{l}\text { Right hypochondrial } \\
\text { pain }\end{array}$ & 48 & 84.21 \\
\hline Fever & 45 & 78.94 \\
\hline Jaundice & 21 & 36.84 \\
\hline Hepatomegaly & 5 & 8.77 \\
\hline
\end{tabular}

Table 4: Location of the liver abscess, $n=57$.

\begin{tabular}{|l|c|c|}
\hline \multicolumn{1}{|c|}{ Location } & Patients (n) & Percentage-\% \\
\hline Right lobe & 38 & 66.66 \\
\hline Left lobe & 19 & 33.33 \\
\hline
\end{tabular}

Table 5: Number of liver abscess, $n=57$.

\begin{tabular}{|l|c|c|}
\hline No. of abscess & Patients (n) & $\begin{array}{c}\text { Percentage- } \\
\text { \% }\end{array}$ \\
\hline Solitary & 45 & 78.94 \\
\hline Multiple & 12 & 21.05 \\
\hline
\end{tabular}

Table 6: Type of liver abscess, $n=57$.

\begin{tabular}{|c|c|c|}
\hline Type & Patients (n) & Percentage-\% \\
\hline Amoebic & 37 & 64.91 \\
\hline Pyogenic & 20 & 35.08 \\
\hline
\end{tabular}

Table 7: Mode of treatment for patients with liver abscess, $\mathrm{n}=57$.

\begin{tabular}{|l|c|c|}
\hline Mode of treatment & $\begin{array}{c}\text { Patients } \\
\text { (n) }\end{array}$ & $\begin{array}{c}\text { Percentage } \\
\text { \% }\end{array}$ \\
\hline $\begin{array}{l}\text { Conservative manage- } \\
\text { ment with antibiotics }\end{array}$ & 12 & 21.05 \\
\hline Aspiration & 15 & 26.31 \\
\hline Pigtail drainage & 26 & 45.61 \\
\hline Open surgery & 4 & 7.01 \\
\hline
\end{tabular}


The liver abscess was found to occur more in the right lobe of the liver $(66.66 \%)$ and a majority of these were a solitary abscess $(78.94 \%)$. Most of the abscess that we encountered in our study was found to be amoebic liver abscess $(64.91 \%)$. Pigtail drainage of the abscess cavity was the most common procedure done and it was performed in 26 patients $(45.61 \%)$.

Serology for antibodies to E. histolytica is a useful adjunctive test for invasive amoebiasis. ELISA for the demonstration of anti-amoebic antibodies in titres greater than 1:400 is considered strong evidence of amoebic liver abscess. However, for diagnostic purposes, titres $>250$ are considered positive. In our study, there were 37 patients $(64.91 \%)$ whose titres were $>250$ and were diagnosed as amoebic liver abscess and in the remaining 20 patients $(35.08 \%)$ the titres were negative and were considered as pyogenic liver abscess.

\section{DISCUSSION}

Patients with liver abscess present to the surgical department with various complaints such as right hypochondrial pain, fever and jaundice. Mohsen et al also showed that fever may occur in both amoebic and pyogenic liver abscess (1). In the study done by Tiwari et al (2), $81 \%$ of patients had fever and in the study done by Rajak et al (3), 92\% of patients had fever. In our study, $84.21 \%$ of patients with liver abscess had fever. Sometimes, patients with a liver abscess may also present with dysentery and this was shown in the study done by Abullah et al (4). It is important to differentiate an amoebic liver abscess from a pyogenic liver abscess and this importance has been shown in the studies done by Ahsan et al (5) and Goh et al (6). In our study, $64.91 \%$ of patients had an amoebic liver abscess and $35.08 \%$ of patients had a pyogenic liver abscess. Investigations such as ultrasound and CT of the abdomen are very useful in determining whether the abscess cavity is solitary or multiple and also in which lobe the cavity is present in. In our study,
$78.94 \%$ of patients had a solitary abscess in the liver and in $66.66 \%$ of patients the abscess was located in the right lobe of the liver. Bukhari et al showed in their study that $83 \%$ of liver abscess were solitary (7). Chou et al. also showed in their study that, $71.01 \%$ patients had a solitary liver abscess and $28.98 \%$ patients had multiple liver abscess (8). In the study done by Tiwari et al (2), $67.2 \%$ of patients had a solitary liver abscess and $32.8 \%$ of patients had multiple liver abscess. In the study done by Rajak et al (3), $80 \%$ of patients had a solitary liver abscess and $20 \%$ of patients had multiple liver abscess. The predominance of liver abscess in the right lobe was also shown in the studies done by Makkar et al (9), Khan et al (10) and Qazi et al (11). Drugs such as metronidazole are very useful in treating patients with amoebic liver abscess. However, sometimes patients will require needle aspiration or pig tail catheter for continuous drainage. Powell et al showed in their study the effectiveness of using metronidazole in treating patients with amoebic liver abscess (12). When aspiration is required, it is better to do it under ultrasound guidance so that the abscess cavity can be visualised and then the pus can be aspirated out. The pus that is aspirated must be sent for culture. The organism that is grown must be noted and the patient must be treated accordingly. Pang et al (13) and Wang et al (14) in their studies demonstrated different organisms that were grown from different patients with liver abscess. Ramani et al (15) showed the need for percutaneous aspiration in their study and Giorgio et al (16) also showed in their study that sometimes there may be a need for repeated aspirations to be done in cases of liver abscess. Most of our patients had drainage of the liver abscess with a pigtail catheter and a few of the patients only needed needle aspiration to drain the pus. Zerem et al (17) and Mcgarr et al (18) also showed in their studies that needle aspiration and percutaneous drainage are extremely useful modalities of treatment in cases of liver abscess.

Table 8: Comparison of clinical features of liver abscess between our study and other studies

\begin{tabular}{|l|c|c|c|}
\hline Clinical feature & Tiwari et al (2) & Rajak et al (3) & Our study \\
\hline $\begin{array}{l}\text { Right hypochondrial } \\
\text { pain }\end{array}$ & $\mathbf{9 8 . 3 \%}$ & $\mathbf{1 0 0 \%}$ & $\mathbf{8 4 . 2 1 \%}$ \\
\hline Jaundice & $\mathbf{3 8 \%}$ & $12 \%$ & $\mathbf{3 6 . 8 4 \%}$ \\
\hline Fever & $\mathbf{8 1 \%}$ & $\mathbf{9 2 \%}$ & $\mathbf{7 8 . 9 4 \%}$ \\
\hline
\end{tabular}

Table 9: Comparison of number of liver abscess between our study and other studies.

\begin{tabular}{|l|c|c|c|c|c|}
\hline Liver abscess & $\begin{array}{l}\text { Tiwari et al. } \\
(\mathbf{2})\end{array}$ & $\begin{array}{l}\text { Rajak et al. } \\
(\mathbf{3})\end{array}$ & $\begin{array}{l}\text { Chou et al. } \\
(\mathbf{8})\end{array}$ & Bukhari et al. (7) & Our study \\
\hline Solitary, \% & 67.2 & 80 & 71.01 & 83 & 78.94 \\
\hline Multiple, \% & 32.8 & 20 & 28.98 & 17 & 21.05 \\
\hline
\end{tabular}




\begin{tabular}{|l|c|c|c|}
\hline \multicolumn{4}{|l|}{ Table 10: Comparison of the type of liver abscess between our study and other studies. } \\
\hline Type of liver abscess & Tiwari et al. (2) & Rajak et al. (3) & Our study \\
\hline Amoebic & 75.9 & 80 & 64.91 \\
\hline Pyogenic & 24.1 & 20 & 35.08 \\
\hline
\end{tabular}

It is also important to know some of the complications that a liver abscess can cause and one such important complication is the thoracic complication of a liver abscess and this was shown in the study done by Perez et al (19). So, it is very important diagnose a patient with a liver abscess as early so that the treatment can be started as early as possible.

\section{Conclusion}

From our study, it is seen that liver abscess are more commonly found on the right lobe of the liver $(66.66 \%)$ and are usually solitary abscess cavities $(78.94 \%)$. In our study, amoebic liver abscess $(64.91 \%)$ was more commonly found than the pyogenic liver abscess $(35.08 \%)$. Our study shows that, when a patient presents with features suggestive of a liver abscess, investigations must be done at the earliest and the liver abscess must be identified and treatment must be started as early as possible.

\section{REFERENCES}

1. Mohsen AH, Green ST, Read RC, McKendrick MW. Liver abscess in adults: ten years experience in a UK centre. QJM 2002;95(12):797802.

2. Tiwari D, Jatav OP, Jain M, Kumar S. Study of clinical and etiopathological profile of liver abscess. J of Evidence Based Med and Healthcare 2015;2(40):6705-12.

3. Rajak CL, Gupta S, Jain S, Chawla Y, Gulati M, Suri S. Percutaneous treatment of liver abscesses: needle aspiration versus catheter drainage. Am J Roentgenol 1998;170(4):1035-9.

4. Abdullah AA. Clinical analysis of Amoebic liver abscess. IJGE 2005;5(1):35-8.

5. Ahsan T, Jehangir MU, Mahmood T, Ahmed N, Saleem M, Shahid M, et al. Amoebic versus pyogenic liver abscess. J Pak Med Assoc 2002;52(11): 497-501.

6. Goh KL, Wong NW, Paramsothy M, Nojeg M, Somasundaram K. Liver abscess in the tropics: experience in the University Hospital, Kuala Lumpur. Postgrade Med J 1987;63(741):551-4.

7. Bukhari AG, Abid KG. Amebic liver abscess: clinical presentation and diagnostic difficulties. KMJ 2003:183-6.6.

8. Chou FF, Sheen-chen SM, Chen YS, Chen MC. Single and multiple pyogenic liver abscesses: clinical course, etiology and results of treatment, World J Surg 1997;21(4)384-8.

9. Makkar RP, Sachdev GK, Malhotra V. Alcohol consumption, hepatic iron load and the risk of amoebic liver abscess: a case-control study. Internal Medicine 2003;42(8):644-9.

10. Khan RA, Hameed F, Bashir MB, Rana MM, Mazhar HR. Amebic liver abscess; incedence and outcome. Professional Med J 2010;17(4).

11. Qazi AR, Naqvi SQ, Solangi RA, Memon JM, Lashari A. Liver Abscess: Diagnosis and Treatment. Pakistan J Surg 2008;24:203-7.

12. Powell SJ, Macleod I, Wilmot AL, Elsdon-Dew E. Metronidazole in amoebic dysentery and amoebic liver abscess. Lancet 1966;2(7477):1329-31.

13. Pang TC, Fung T, Samra J, Hugh TJ, Smith RC. Pyogenic liver abscess: An audit of 10 years' experience. World J Gastroenterol 2011;17(12): 1622-130.

14. Wang JH, Liu YC, Lee SS, Yen MY, Chen YS, Wang JH, et al. Primary Liver Abscess due to Klebsiella pneumonia in Taiwan. Clin Inf Dis 1998;26(6):1434-8.

15. Ramani A, Ramani R, Kumar MS, Lakhkar B, Kundaje GN. Ultrasound guided needle aspiration of amoebic liver abscess. Postgrad Med J 1993; 69(811):381-3.

16. Giorgio A, Amoroso P, Francica G, de Stefano G, Fico P, Lettieri G, et al. Echo guided percutaneous puncture: a safe and valuable therapeutic tool for amoebic liver abscess. Gastrointest Radiol 1988; 13(4):336-40.

17. Zerem E, Hadzic A. Sonographically guided Percutaneous catheter drainage versus Needle aspiration in the management of Pyogenic liver abscess. Am J Radiol 2007;189(3):W138-42.

18. McGarr PL, Madiba TE, Thomson SR, Corr P. Amoebic liver abscess-Results of a conservative management policy. SAMJ 2003;93(2):132-6.

19. Perez CI. Thoracic complications of Amoebic abscess of Liver. Chest 1981;79(6):672-7. 